\section{Stench on the New Jersey Turnpike}

SIR, - The central point in Thomas Jukes' recent review of Malignant Neglect $(8$

November, page 166) - that the book treats facts cavalierly - is amply documented by the quotations he cites. I should like to point out, however, that Professor Jukes' own attitude to facts is not beyond criticism.

Jukes quotes the book's description of the "stench" and emissions from the large petrochemical complex near the New Jersey

Turnpike, which (it implies) is related to 14,000 cancer deaths in New Jersey. He then dismisses the statements on the grounds that he once drove the same route at $6.45 \mathrm{pm}$ and observed neither stench nor emissions, apart from steam.

Having myself travelled this route, by car or train, at least 50 times over the past 20 years, I can assure Professor Jukes that the petrochemical stink in the area is no man's invention. Since I did not keep score, I cannot swear to how often I experienced it - but it was often enough for the experience to become an absolutely expectable feature of the trip.

Jukes' own account provides a clear explanation of why he smelt nothing assuming, of course, that the complex was in operation at $6.45 \mathrm{pm}$. "To the west," he notes, "there was a brilliantly clear sunset in which a range of hills, 30 miles away, was sharply etched against the sky." That degree of visibility could exist only amid a continenta polar air mass entering the area - which is normally associated with northwesterly winds. The complex lies southeast of the highway.

New Jersey does in fact have one of the highest cancer rates in the US. Whether this has any connection with emissions from the chemical manufacturing facilities with which northern New Jersey is sown has yet to be established. However, a number of reputable authorities, including the US Public Health Service, consider the possibility real enough to be worth investigating. Yours faithfully,

ROBERT CLAIBORNE

New York, US

\section{Research ceased during the Cultural Revolution}

SIR, - Having recently returned from working at the Institute of Vertebrate Palaeontology and Palaeoanthropology in Peking I would like to challenge Tilman Spengler's assertion (15 November, page224) that this was one of the institutes of the Chinese Academy of Sciences that "worked very well" during the Cultural Revolution. Certainly the institute was not physically closed down, but a research institute where no research is permitted, can hardly be said to be working well. By 1972 research activity was starting up again, but for six years nothing was heard of vertebrate palaeontologists or their work. The Chinese vertebrate palaeontology journal Vertebrata Palasiatica ceased publication in 1966 and did not reappear until 1973. The impression gained from my Chinese colleagues was that the Cultural Revolution was a period of enforced isolation and stagnation.

Finally, I would like to comment upon the statement attributed to the three Chinese scientists visiting Britain: 'In China we tend to work more collectively. It is unheard of for an individual to work alone . . . I suspect this comment may well have arisen from a semantic misunderstanding. Certainly from my observations, Chinese scientists in my own field, at least, work exactly as they do in Britain. The individual scientist is employed with others in an institute, will collect raw data jointly with colleagues, will discuss his or her results with colleagues, may cooperate with others to produce joint papers, but in the main does scientific research alone. This much is evident from even a cursory glance at the authorship of Chinese scientific publications. Yours faithfully,

L.B. HALSTEAD

University of Reading, $U K$

\section{China has many aspects}

SIR, - In your introduction to the two reports on "China: the legacy of the Cultural

Revolution"' (15 November, page 224), you used the phrase "views of China are as diverse as its visitors", and seemed to imply a disagreement between myself and Tilman Spengler. I would like to point out, however, that the diversity is a reflection of the "diverse aspects of the problem", and not necessarily a "diversity of opinions"'. Spengler discussed policies, which had their positive sides; I was talking about the excution of some of the policies, which led to intense suffering by some people.

My report was written shortly after my return when the depressing discoveries of the suffering by my friends and relatives were still fresh in my memory. If I had been more emotional than I need to be, my motives could be understood, if not forgiven.

Finally, I inadvertently used the expression "tradition-bound arrogance" when I really meant to say "tradition-bound smugness". I am sorry for the unfortunate choice of a word that has been offensive, when no of fence was intended.

$$
\text { Yours faithfully, }
$$

Ken HsU

ETH, Zürich, Switzerland

\section{New select committee seeks expertise}

SIR, - The Education, Science and Arts Committee held their first meeting on Thursday, 29 November.

In recommending the setting up of the new select committees, the Procedure Committee stated, "We hope that, as the new committees become established ... they will develop methods of work which will enable them to respond more speedily to current problems and to new policy proposals". In view of this we have decided to study a number of subjects and report fairly rapidly during the coming year. By fairly rapidly we mean we are trying to set ourselves a maximum time of two months between starting to take evidence and reporting. We have facilities to hire specialist assistance. We have not yet decided which shall be our first subjects of study but we expect them to be in the field of education.
The Committee are anxious to ascertain what specialist assistance might be available to them in their investigations, and I have therefore written to a number of institutions asking if and how they are able to help. But the committee would also like to hear from any individuals and other organisations who feel they have the individuals and other organisations who feel they have the necessary expertise, and I am therefore seeking the hospitality of your columns to make this request.

\section{Yours faithfully,} CHRISTOPHER PRICE MP

House of Commons, London UK

\section{Research councils: do they pay the real cost?}

SIR, - I should like to publicise an unfortunate consequence of the restrictions which grant-awarding bodies such as the Science Research Council place on the use to which their grants may be put. In general the recipient is not allowed to use the money to pay for computing, telephoning, typing, photocopying, page charges for publishing, library facilities, recruitment advertising, removal expenses for staff appointed, or redundancy pay. Instead, the host institution is assumed to be capable of paying for all of these. This is unquestionably no longer true. The result of this is that the more active a department or institution is, the closer it is brought to bankruptcy by its scientific endeavour. I would suggest that small institutions are particularly vulnerable to this. Is it not about time that the research council faced up to their responsibility and paid the full cost of a research project? Is it really our government's policy to encourage its academic scientists to lay low and do nothing because the funds provided are not sufficient to cover the real cost of their projects?

Yours faithfully,

AlanD.B. MaLCOLM

St Mary's Hospital Medical School, London UK

\section{$X$ as the $Y$ of $Z$}

SIR, - In your review of Horace Judson's The Eighth Day of Creation (11 October, page 506) I am called "a sort of Louella Parsons of molecular biology" apparently, because I told Judson that I thought a friend of mine is its Douanier Rousseau (a painter whom I very much admire). Here your reviewer is not far off the mark: long ago I picked up the habit of styling $\mathrm{X}$ as the $\mathrm{Y}$ of $\mathrm{Z}$ at a party in Hollywood, where I heard Christopher Isherwood say that Wagner is the Puccini of music.

Before finally kicking the habit, may I coin one final simile? Namely, if The Eighth Day of Creation really showed as much lack of historical comprehension as your reviewer found it to show, then Judson would be the Thomas Jukes of molecular biology. Yours faithfully, GUNTHer S. STENT

University of California, Berkeley, US. 